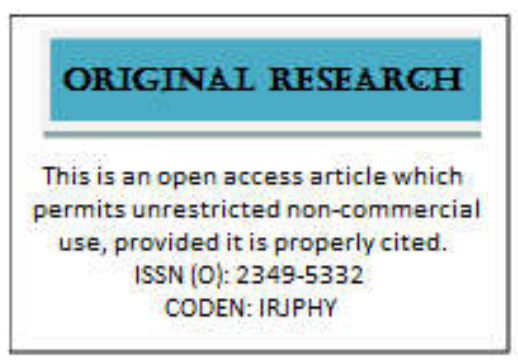

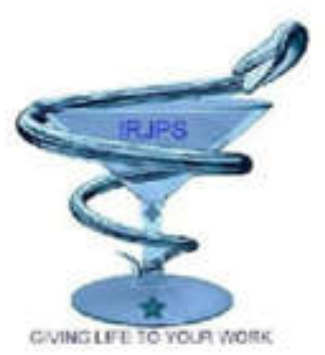

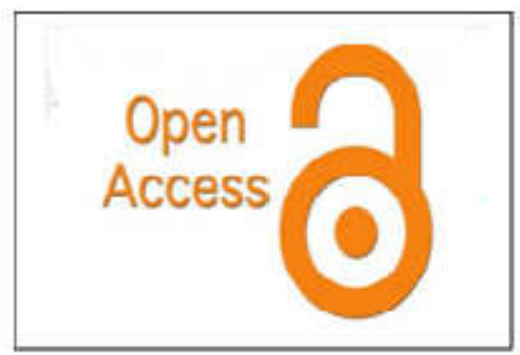

\title{
FREE RADICAL SCAVANGING ACTIVITY IN CYCLOPHOSPHAMIDE INDUCED OXIDATIVE STRESS IN BRAIN USING ALANGIUM SALVIIFOLIUM
}

\author{
Shankar, Anup Kumar Chakraborty*, Sarita Karole, Kavita R Loksh \\ Oriental College of Pharmacy, Raisen Road, Patel Nagar, Bhopal - 462021
}

\begin{abstract}
:
Alangium salvifolium is a deciduous shrub or small tree grows upto 3 to $10 \mathrm{~m}$ height, with more or less spinescent branches and pale brown bark with rough surface and trunk with numerous holes. Leaves 7.6-15.2 cm long, alternate, simple, without stipules, narrowly oblong or ovate-lanceolate, glabrous, petiole up to $1.5 \mathrm{~cm}$ long, hairy. Flowers bisexual, regular, 5-10 merous, white, few in axillary fascicles. Fruits are small, nearly globular, purplishred when ripe, crowned by persistent calyx-limb. The flowering season is February to June. During, Second World War nitrogen mustards were used as agents in chemical war-fare which made researchers to pay more attention towards their application. The new area of research in the discovery and synthesis of nitrogen mustard derivatives was launched in the late 1950's and early 1960's.
\end{abstract}

KEYWORDS: Alangium salvifolium, phytochemical investigation, Alangium decapetalum Lam

Corresponding author: Anup K Chakraborty Email id: anup.ckbty@yahoo.co.in
Indian Research Journal of Pharmacy and Science; 26(2020)2453-2459; Journal Home Page: https://www.irjps.in DOI: $10.21276 /$ irjps.2020.7.4.6 


\section{INTRODUCTION}

Cyclophosphamide: Cyclophosphamide which soon came into extensive use. Being aware of the fact that, $\mathrm{CP}$ is one such anticancer drug with bifunctional alkylating agent ${ }^{1}$ belongs to the class of nitrogen mustard widely used with high therapeutic index and broad spectrum of activity to treat lymphomas, myeloma, solid tumors, chronic lymphocytic leukemia, and as an immunosuppressant in autoimmune disorders and in the bone marrow preparation for transplantation ${ }^{2}$. Further, CP destroys other normal cells which are its major drawback. These active metabolites produces irreversible crosslink in both intra and inter DNA strands by adding an alkyl group $(\mathrm{CnH} 2 \mathrm{n}+1)$ to the guanine bases of DNA, at the N-7 position of the imidazole ring thereby inhibit DNA replication and repair that lead to cell death through apoptosis. Further, $\mathrm{CP}$ put forth its cytotoxic effect equally on resting and dividing lymphocytes. CP works at any point in the cell cycle and is a cell cycle independent drug. Hence, the impact on the cells mainly depends on the dose; the fraction of cells that die is directly proportional to the dose of drugs.

Alangium salvifolium commonly known as sageleaved alangium is a flowering plant and Botanical name "Alangium salvifolium walgerin" belonging to family "Alangiaceae".

SYNONYMS: Alangium decapetalum Lam. Alangium lamarckii Thwaites Alangium salviifolium subsp. decapetalum (Lam.) Wangerin Alangium tomentosum Lam.

Chemical constituents: The Alangium salvifolium consist different phytoconstituents ${ }^{3}$ in different part of the plant. Leaves, roots and seeds of Alangium salvifolium contain the alkaloids (like alangidiol, alangicine, alangimarckine, alamaridines, dimethyl aptaline, iso alamarin, alangimarinone, dimethyl phycotrine, ankorine ${ }^{4}$ marckidine, marckine, tubulosine, alangicine, cephaeline, psychotrine), steroids (alangol, alengol), triterpenoids flavonoids, steroids, glycosides, tannins, oil and saponins. Plant (root, leaves and fruit) also consist monoterpenoid lactam $^{5}$, alangiside, loganic acid, venoterpine, dl- salsoline and isocephaeline. Leaves of Alangium salvifolium contain alkaloids, deoxytubulosine, alangimarckine, dehydroprotoemetine etc.

Habit: A bulbous biennial or perennial sub-erect herbs Habitat: A rare tree in coastal areas but grows vigorously in forests of southern India and found throughout the drier parts of India

Stem: A. salvifolium is a small tree grows upto 3 to $10 \mathrm{~m}$ height, with more or less spinescent branches and pale brown bark with rough surface and trunk with numerous holes.

Leaves: The leaves of A.salvifolium are simple, petiolate, alternate, dorsiventral and glabrous on both the sides, shaped oblong-lanceolate; base rounded, apex is acute and the margins are entire. The venation of the leaf is reticulate with prominent midrib. The size of each leaflet is $4-15 \mathrm{~cm}$ long and $3-4 \mathrm{~cm}$ wide. The fresh leaves are green in color, odorless and without any taste.

Flower: Flowers are white sub-silky, ebracteate, short pedicelled and appear during February to April.

Fruits and Seeds: Fruits are ellipsoidal when young and become purplish red globular when ripen. Seeds are single ovoid with bony foliaceous endocarp ${ }^{6}$.

\section{MEDICINAL PROPERTIES}

1. The leaves of Alangium salviifolium are used as astringent, laxative ${ }^{7}$, refrigerant. It is used for the treatment of rheumatism, leprosy, gastric ulcers; Wound healing, epilepsy, scabies, gonorrhea, jaundice, hepatitis, diabetes, syphilis and asthma.

2. The root bark is used as purgative, astringent, anthelmintic, antipyretic, expectorant, antiinflammatory, emetic, diaphoretic, anticancer, antimicrobial and antitumor agents.

3. The root is used as hypotensive agent, anthelmintic and used in the treatment of biliousness, inflammation, diarrhea, piles, paralysis, vomiting, skin diseases and snakebite. The bark shows anti tubercular activity $^{8}$.

4. The fruits are used as laxative, refrigerant, emetic and antiphlegmatic agent, whereas the seeds are used in hemorrhage, leprosy. Stem is used in vomiting and diarrhea 9 


\section{TRADITIONAL USES}

1. Root bark used as astringent, spasmolytic, hypotensive, diaphoretic and antipyretic and leaves in the treatment hypoglycaemic. Fruits are acidic and used as astringent, laxative and refrigerant. Used in haemorrhages, strangury and consumption.

2. The bark is used as a substitute for Cephaelisipecacuanha ${ }^{10}$. It is a rich source of alkaloids structurally related to ipecac alkaloids.

3. The leaves of Alangium salviifolium are used as astringent, laxative, refrigerant. It is used for the treatment of rheumatism, leprosy, gastric ulcers; Wound healing, epilepsy, scabies, gonorrhea, jaundice, hepatitis, diabetes, syphilis and asthma.

4. The root is acrid, bitter, slightly pungent and used as anthelminthic, purgative and treatment of biliousness and inflammations. The root bark is use in piles, anthelmintic and purgative. The leaves are used as a poultice to relieve rheumatic pain.

5. The bark is bitter and good substitute to ipecacuanha and used as antipyretic and lowering blood pressure. Both root and bark are prescribed as antidotes to snake venom.

\section{MATERIAL AND METHOD:}

\section{Selection of plant and authentication:}

Fresh fruit Alangium salviifolium was collected from the cultivated farm and the open field of Bhopal and authenticated by botanist from the Department of Botany, Safia Science College having plant authentication number $057 / \mathrm{bot} / \mathrm{saf} / 20$. Four hundred gram of the powder vacuum evaporator (Bucchi type) at $40^{\circ} \mathrm{C}$. The percentage yield of the extract was $2.43 \%$, based on the starting quantity. The doses of 200 and $400 \mathrm{mg} / \mathrm{kg}$ body weight (b.w.) were prepared by suspending the dried extract in water and administering it to the rats by the per OS (p.o.) route. prepared from shade-dried fruit was subjected to Soxhlet extraction for $16 \mathrm{~h}$ using Petroleum ether $\left(40-60^{\circ} \mathrm{C}\right)$ as nonpolar solvent at first. Exhausted plant material (marc) was dried and then extracted ${ }^{11}$ with ethanol. Colorless solvent was collected from siphon tube and evaporated for residue. Absence of residue confirmed the completion of extraction. Obtained extracts were evaporated using rotary $^{12}$.

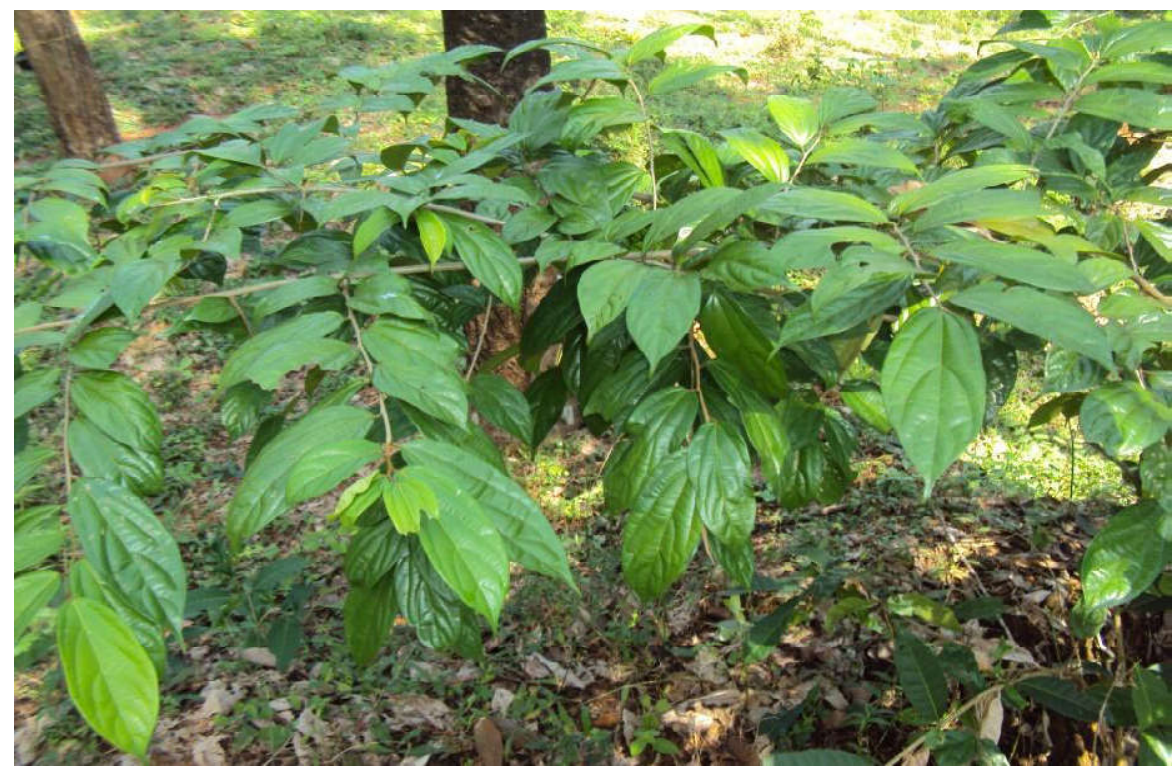

Fig. No. 1: Plant of Alangium salviifolium 


\section{Extraction of Plant material:}

In the present study, extraction was performed using continuous hot percolation 'Soxhlation'. Dried pulverized fruit of Alangium salviifolium were placed in thimble of Soxhlet apparatus. Soxhlation was performed at $60^{\circ} \mathrm{C}$ using Petroleum ether $\left(40-60^{\circ} \mathrm{C}\right)$ as nonpolar solvent at first ${ }^{13}$. Exhausted plant material (marc) was dried and then extracted with ethanol. For confirmation of exhausted plant marc (i.e. completion of extraction), colourless solvent was collected from siphon tube and evaporated for residue. Absence of residue confirmed the completion of extraction. Obtained extracts were evaporated using rotary vacuum evaporator (Bucchi type) at $40^{\circ} \mathrm{C}^{14}$.

\section{Tests for Carbohydrates:}

Fehling's Test 1 To $1 \mathrm{ml}$ of ethanolic extract, $1 \mathrm{ml}$ of Fehling's A and $1 \mathrm{ml}$ of Fehling's B solutions were added in a test tube and heated in the water bath for 10 minutes. Formation of red precipitate indicates the presence of reducing sugar.

Benedict's Test Equal volume of Benedict's reagent and ethanolic due to formation of cupric oxide indicates the presence of monosaccharide.

Barfoed's Test $1 \mathrm{ml}$ of extract and Barfoed's reagent were mixed in a test tube and heated on water bath for 2 minutes. Red colour due to formation of cupric oxide indicates the presence of monosaccharide.

\section{Tests for Protein and Amino acids:}

Biuret's Test The extract was treated with $1 \mathrm{ml}$ of $10 \%$ sodium hydroxide solution in a test tube and heated. A drop of $0.7 \%$ copper sulphate solution was added to the above mixture. The formation of violet or pink colour indicates the presence of proteins.

\section{Tests for Glycosides:}

Borntrager's Test To $3 \mathrm{ml}$ of test solution, dilute sulphuric acid was added, boiled for 5 minutes and filtered. To the cold filtrate, equal volume of benzene or chloroform was added and shake it welled. The organic solvent layer was separated and ammonia was added to it. Formation of pink to red color in ammoniacal layer indicates presence of anthraquinone glycosides.

Legal's Test $1 \mathrm{ml}$ of test solution was dissolved in pyridine. $1 \mathrm{ml}$ of sodium nitropruside solution was added and made alkaline using 10\% sodium hydroxide solution. Formation of pink to blood red color indicates the presence of Cardiac glycosides.

Keller-Killiani Test To $2 \mathrm{ml}$ of test solution, $3 \mathrm{ml}$ of glacial acetic acid and 1 drop of 5\% ferric chloride were added in a test tube. Add carefully $0.5 \mathrm{ml}$ of concentrated sulphuric acid by the side of the test tube. Formation of blue color in the acetic acid layer indicates the presence of Cardiac glycosides.

\section{Tests for Alkaloids:}

Mayer's Test To 2-3 $\mathrm{ml}$ of filtrate, few drops of Mayer's reagent were added along sides of tube. Formation of white or creamy precipitate indicates the presence of alkaloids.

Hager's Test To 1-2 $\mathrm{ml}$ of filtrate, few drops of Hager's reagent were added in a test tube. Formation of yellow color precipitate indicates the presence of alkaloids.

Wagner's Test To 1-2 $\mathrm{ml}$ of filtrate, few drops of Wagner's reagent were added in a test tube. Formation of reddish brown precipitate indicates the presence of alkaloids.

\section{Tests for Saponins:}

Froth Test The extract was diluted with distilled water and shaken in graduated cylinder for 15 minutes. The formation of layer of foam indicates the presence of saponins.

\section{Tests for Flavonoids:}

Lead Acetate Test The extract was treated with few drops of lead acetate solution. Formation of yellow precipitate may indicate the presence of flavonoids.

Alkaline Reagent Test The extract was treated with few drops of sodium hydroxide separately in a test tube. Formation of intense yellow color, which becomes color less on addition of few drops of dilute acid, indicate presence of flavonoids.

\section{Tests for Triterpenoids and Steroids:}

Salkowski's Test The extract was treated with chloroform and filtered. The filtrate was added with few drops of concentrated sulphuric acid, shaken and allowed to stand. If the lower layers turns red, sterol are present. Presence of golden yellow layer at bottom indicates the presence of triterpenes ${ }^{15}$. 
Libermann- Burchard's Test The extract was treated with chloroform. To this solution few drops of acetic anhydride were added, boiled and cooled. Concentrated sulphuric acid was added through the sides of the test tube. Formation of brown ring at the junction of two layers, if upper layer turned green, indicate presence of steroids and formation of deep red color indicate presence of triterpenoids.

Tests for Tannin and Phenolic compounds:

Ferric Chloride Test Some amount of extract was dissolved in distilled water. To this solution $2 \mathrm{ml}$ of $5 \%$ ferric chloride solution was added. Formation of blue, green or violet color indicates presence of phenolic compounds ${ }^{16}$.

Lead Acetate Test Some amount of extract was dissolved in distilled water. To this solution few drops of lead acetate solution was added. Formation of white precipitate indicates presence of phenolic compounds.

Gelatin Test Some quantity of extract dissolved in distilled water. To this solution $2 \mathrm{ml}$ of $1 \%$ gelatin solution containing $10 \%$ sodium chloride was added. Development of white precipitate indicates presence of phenolic compounds.

Tests for Fats and Oils A Small quantity of extract was pressed between two filter papers. The appearance of permanent spot oil on the paper indicates the presence of fixed oils.

Solubility test $2-3 \mathrm{ml}$ of the alcoholic solution of extract, add few $\mathrm{ml}$ of chloroform and solubility was observed. 2-3 $\mathrm{ml}$ of the alcoholic solution of extract, add few $\mathrm{ml}$ of $90 \%$ ethanol and solubility was observed $^{17}$.

\section{RESULT:}

DPPH assay The DPPH test provides information on the reactivity of the test compounds with a stable free radical. The free radical scavenging activities Alangium salviifolium extracts were assessed by DPPH. As shown Alangium salviifolium extract exhibited a significant inhibitory activity against the DPPH radical.

Table 1: Values for DPPH radicals in Alangium salviifolium extract

\begin{tabular}{|c|c|c|c|}
\hline S. No. & Conc. $(\boldsymbol{\mu g} / \mathbf{m l})$ & Ascorbic acid (\% Inhibition) & Ethanolic Extract (\% Inhibition) \\
\hline $\mathbf{1 .}$ & 20 & 43.4511 & 34.52201 \\
\hline $\mathbf{2 .}$ & 40 & 49.04521 & 38.54272 \\
\hline $\mathbf{3 .}$ & 60 & 55.24585 & 42.81747 \\
\hline $\mathbf{4 .}$ & 80 & 61.15492 & 47.73862 \\
\hline $\mathbf{5 .}$ & 100 & 69.48512 & 52.68669 \\
\hline \multicolumn{2}{|c|}{ IC 50 Value } & $\mathbf{4 2 . 4 3}$ & $\mathbf{8 9 . 8 6 7}$ \\
\hline
\end{tabular}

Reducing power assay: Reducing power assay measures the electron donating capacity of an antioxidant. The reducing power of Alangium salviifolium extracts are summarized. From the figure, reducing power increased with an increased in extracts concentration. Butylated hydroxy toluene (BHT) was used as standard.

Table 2: Reducing power assay activity of Ascorbic acid and Alangium salviifolium

\begin{tabular}{|c|c|c|c|}
\hline S. No. & Conc. $(\boldsymbol{\mu g} / \mathbf{m l})$ & BHT & Ethanolic Extract \\
\hline $\mathbf{1 .}$ & 10 & 0.081 & 0.063 \\
\hline $\mathbf{2 .}$ & 20 & 0.094 & 0.076 \\
\hline $\mathbf{3 .}$ & 40 & 0.12 & 0.099 \\
\hline $\mathbf{4 .}$ & 60 & 0.139 & 0.121 \\
\hline $\mathbf{5 .}$ & 80 & 0.16 & 0.137 \\
\hline $\mathbf{6 .}$ & 100 & 0.18 & 0.161 \\
\hline
\end{tabular}




\section{IN VIVO ANTIOXIDANT ASSAY}

Lipid peroxidation: Lipid peroxidation MDA is a marker of LPO, the rate of MDA increased from 12.64 \pm 0.16 (control) for 6 days. A significant depletion in the lipid peroxide level was observed after post treatment of AS $(200 \mathrm{mg} / \mathrm{kg})$ and AS $(200 \mathrm{mg} / \mathrm{kg})$ extracts as compared to CYP group $14.52 \pm 0.13$. AS $(400 \mathrm{mg} / \mathrm{kg})$ attenuated LPO levels as $12.5 \pm 0.08$ in brain $(\mathrm{P}<0.05)$

Reduced glutathione: GSH level decreased from 13.77 \pm 0.22 (control) in brain after CYP treatment as compared to control. Post administration of AS $(200 \mathrm{mg} / \mathrm{kg})$ and AS $(400 \mathrm{mg} / \mathrm{kg})$ significantly increased the level of GSH as compared to inducer group. AS $(400 \mathrm{mg} / \mathrm{kg})$ recovered the GSH level $6.88 \pm 0.608$ whereas AS $(200 \mathrm{mg} / \mathrm{kg}) 5.75 \pm 0.94$ as in brain.

Superoxide dismutase: SOD activity inhibited from $71.64 \pm 2.05$ (control) and $84.94 \pm 1.93$ (inducer) in brain by inducer. Post administration of AS $(200 \mathrm{mg} / \mathrm{kg})$ and AS $(400 \mathrm{mg} / \mathrm{kg})$ significantly protect the level of SOD in comparison to control group.AS $(400 \mathrm{mg} / \mathrm{kg}$ ) enhanced the level of SOD as $46.67 \pm 0.652$ whereas $40.71 \pm 1.171 \mathrm{AS}(200 \mathrm{mg} / \mathrm{kg})$ in brain.

\section{DISCUSSION:}

The most prominent and natural way to defense against the oxidative stress is the antioxidants. In particular flavonoids have been found to possess antiinflammatory, antioxidant, antiallergic, neuro protective, antithrombotic and anti-carcinogenic effects. Cyclophosphamide is an antineoplastic agent metabolized to active alkylating metabolites, widely used alkylating agents that damage normal cells while killing cancerous cells in vivo by slowing or stopping cell growth. It also possesses marked immunosuppressant properties. Oxidative stress is resulted by excessive free radicals. Brain is a highly specialized organ any damage or form of stress experienced in this part of the body may have serious impact on the entire organism. The brain consumes $20 \%$ of their metabolic oxygen. The brain and nervous system are particularly vulnerable to oxidative stress due to limited antioxidant capacity. Have only moderate levels of both enzymatic and nonenzymatic scavengers of reactive oxygen species. It is widely used to treat various types of cancer, in combination with other agents. The use of $\mathrm{CP}$ in treating cancer patients is limited due to its severe toxicities induced mainly oxidative stress. A significant depletion in the lipid peroxide level was observed after post treatment of AS $(200 \mathrm{mg} / \mathrm{kg})$ and AS $(200 \mathrm{mg} / \mathrm{kg})$ extracts as compared to CYP group $14.52 \pm 0.13$. AS $(400 \mathrm{mg} / \mathrm{kg})$ attenuated LPO levels as $12.5 \pm 0.08$ in brain $(\mathrm{P}<0.05)$ Reduced glutathione GSH level decreased from $13.77 \pm 0.22$ (control) in brain after CYP treatment as compared to control. Post administration of AS $(200 \mathrm{mg} / \mathrm{kg})$ and AS $(400 \mathrm{mg} / \mathrm{kg})$ significantly increased the level of GSH as compared to inducer group. AS $(400 \mathrm{mg} / \mathrm{kg}$ ) recovered the GSH level $6.88 \pm 0.608$ whereas AS $(200 \mathrm{mg} / \mathrm{kg}) 5.75$ \pm 0.94 as in brain. Superoxide dismutase SOD activity inhibited from $71.64 \pm 2.05$ (control) and $84.94 \pm 1.93$ (inducer) in brain by inducer. Post administration of AS $(200 \mathrm{mg} / \mathrm{kg})$ and AS $(400 \mathrm{mg} / \mathrm{kg})$ significantly protect the level of SOD in comparison to control group.AS $(400 \mathrm{mg} / \mathrm{kg})$ enhanced the level of SOD as $46.67 \pm$ 0.652 whereas $40.71 \pm 1.171 \mathrm{AS}(200 \mathrm{mg} / \mathrm{kg})$ in brain.

\section{CONCLUSION:}

Present study concluded that the plant extract of Alangium salviifolium administration were able to attenuate the stress-induced oxidative damage in brain. Therefore, it is clear by studying different biochemical parameters that the extract is affected but in different manner. Thus the study indicates Alangium salviifolium are potential candidates for further evaluation as an antioxidant to attenuate stress induced oxidative damage. Further studies will be needed to purify the bioactive compound(s) in the ethanolic extract, and use the purified compound(s) for bioassay directed experiments.

\section{REFERENCES:}

1. Abdalla DS, Monteiro HP, Oliveira JA, and Bechara EJ Activities of superoxide dismutase and glutathione peroxidase in schizophrenic and manic-depressive patients. Clin Chem 1986;32; 805-807.

2. Abramov AY and Duchen MR The role of an astrocytic NADPH oxidase in the neurotoxicity of amyloid beta peptides. Philos Trans R Soc Lond B Biol Sci 2005 ; 360: 2309-2314. 
3. Altuntas I, Aksoy H, Coskun I, Cayköylü A, and Akçay F Erythrocyte superoxide dismutase and glutathione peroxidase activities, and malondialdehyde and reduced glutathione levels in schizophrenic patients. Clin Chem Lab Med 2000; 38: 1277-1281.

4. Andreazza AC, Kauer-Sant'anna M, Frey BN, Bond DJ, Kapczinski F, Young LT, and Yatham LN Oxidative stress markers in bipolar disorder: a metaanalysis. J Affect Disord 2008;111:135-144.

5. Behr GA, Moreira JC, and Frey BN Preclinical and clinical evidence of antioxidant effects of antidepressant agents: implications for the pathophysiology of major depressive disorder. Oxid Med Cell Longev 2012: 421-609.

6. Belmaker RH and Agam G Major depressive disorder. N Engl J Med 2008 ;358:55-68.

7. Berk M, Dean O, Cotton SM, Gama CS, Kapczinski F, Fernandes BS, Kohlmann K, Jeavons S, Hewitt K, Allwang $\mathrm{C}$, et al. The efficacy of $\mathrm{N}$-acetylcysteine as an adjunctive treatment in bipolar depression: an open label trial. J Affect Disord 2011;135: 389-394.

8. Bouayed J, Rammal H, and Soulimani R Oxidative stress and anxiety: relationship and cellular pathways. Oxid Med Cell Longev 2009; 2:63-67.

9. Brown SM, Henning S, and Wellman CL Mild, short-term stress alters dendritic morphology in rat medial prefrontal cortex. Cereb Cortex 2005; 15:17141722.

10. Buckman TD, Kling AS, Eiduson S, Sutphin MS, and Steinberg A Glutathione peroxidase and CT scan abnormalities in schizophrenia. Biol Psychiatry 1987; 22: 1349-1356.
11. Buckman TD, Kling A, Sutphin MS, Steinberg A, and Eiduson S, Platelet glutathione peroxidase and monoamine oxidase activity in schizophrenics with CT scan abnormalities: relation to psychosocial variables. Psychiatry Res 1990;31:1-14.

12. Chang BJ, Jang BJ, Son TG, Cho IH, Quan FS, Choe NH, Nahm SS, and Lee JH Ascorbic acid ameliorates oxidative damage induced by maternal lowlevel lead exposure in the hippocampus of rat pups during gestation and lactation. Food Chem Toxicol 2012; 50:104-108.

13. Cruz-Sánchez FF, Gironès X, Ortega A, Alameda F, and Lafuente JV Oxidative stress in Alzheimer's disease hippocampus: a topographical study. J Neurol Sci 2010; 299:163-167.

14. Dumont M, Wille E, Stack C, Calingasan NY, Beal MF, and Lin MT Reduction of oxidative stress, amyloid deposition, and memory deficit by manganese superoxide dismutase overexpression in a transgenic mouse model of Alzheimer's disease. FASEB J 2009;23:2459-2466.

15. Gandhi $\mathrm{S}$ and Abramov AY Mechanism of oxidative stress in neurodegeneration. Oxid Med Cell Longev 2012:428010.

16. Gawryluk JW, Wang JF, Andreazza AC, Shao L, and Young LT Decreased levels of glutathione, the major brain antioxidant, in post-mortem prefrontal cortex from patients with psychiatric disorders. Int $J$ Neuropsychopharmacol 2011;14:123-130.

17. Huang TT, Zou Y, and Corniola R Oxidative stress and adult neurogenesis effects of radiation and superoxide dismutase deficiency. Semin Cell Dev Biol 2012;23: 738-744. 